Review

\title{
Non-destructive analysis and testing of museum objects: An overview of 5 years of research
}

\author{
Annemie Adriaens * \\ Ghent University, Department of Analytical Chemistry, Krijgslaan 281-S12, 9000 Ghent, Belgium
}

Received 18 August 2005; accepted 7 October 2005

\begin{abstract}
This paper gives an overview of research in or associated with the pan-European network COST Action G8, which aims at achieving a better preservation and conservation of our cultural heritage by increasing the knowledge of art and archaeological objects through advanced chemical and physical analyses. The paper is focussed on the use of various analytical techniques for the examination of cultural heritage materials and includes research examples on painted works of art, ceramics, glasses, glazes and metals. In addition attention is drawn to advances in analytical instrumentation, for example the development of portable techniques to perform analyses on site, and to the need for collaboration between people directly involved in the field of cultural heritage and analytical scientists.
\end{abstract}

(C) 2005 Elsevier B.V. All rights reserved.

Keywords: Cultural heritage; Non-destructive analysis; Inorganic material

\section{Contents}

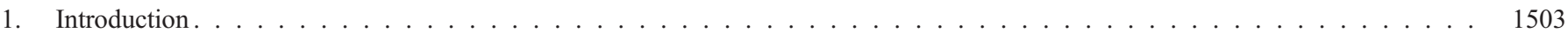

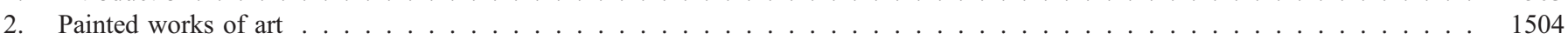

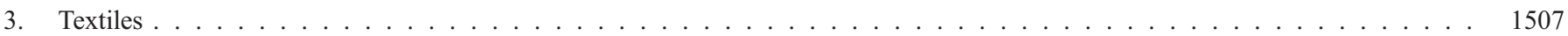

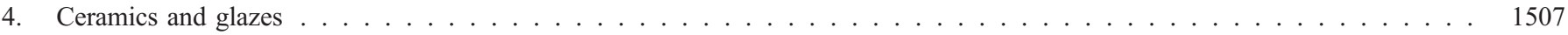

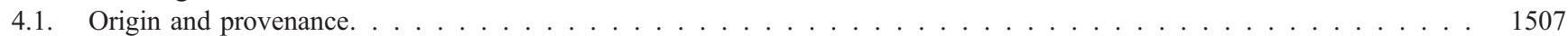

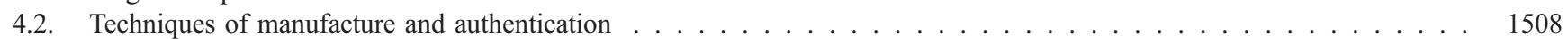

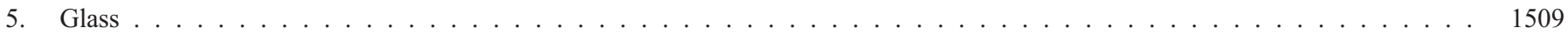

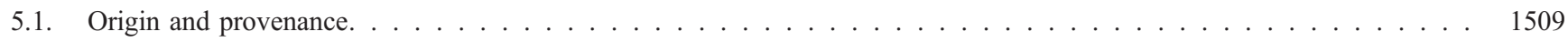

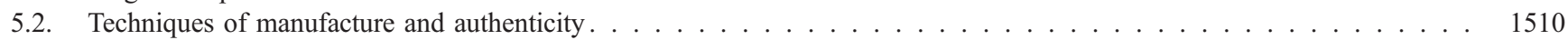

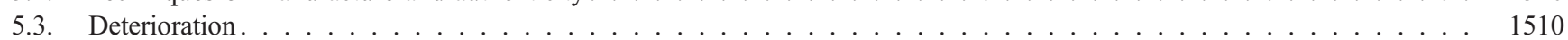

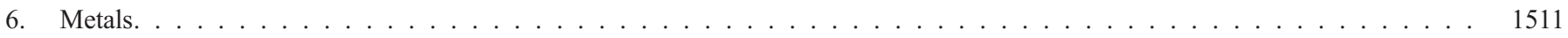

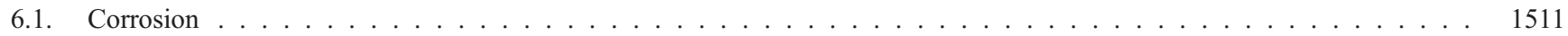

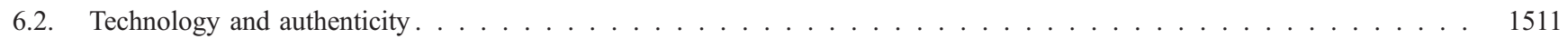

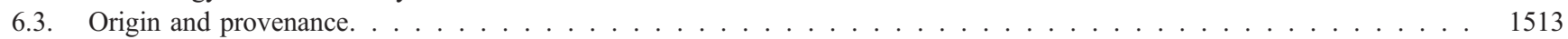

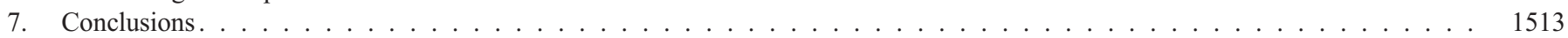

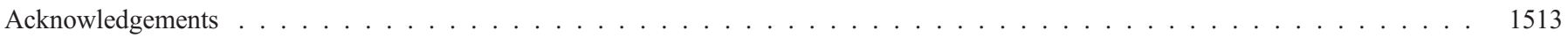

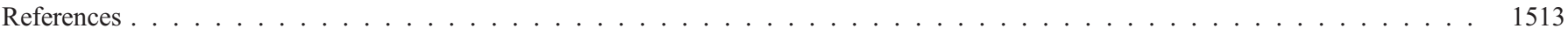

\section{Introduction}

* Tel.: +32 9264 4826; fax:+32 92644960 .

E-mail address: annemie.adriaens@ugent.be.
The conservation and preservation of our cultural heritage is one of the main concerns within Europe today. Its physical part 
is deteriorating faster than it can be conserved, restored or studied. Assets are being lost, or are at risk, through natural processes of decay (sometimes accelerated by poor environmental control), environmental disasters (sometimes exacerbated by human activity), the direct effects of enhanced public access (without commensurate conservation measures), conservation/preservation procedures whose long-term effects were and are not understood, simple negligence, looting and war $[1,2]$.

Advanced analytical methods and techniques are an essential prerequisite in this field as they provide the means to understand the objects under investigation. Through the identification of materials and processes, we can reach back through time and develop a deeper understanding of the craftsmanship and technology that was used. Advanced analytical methods also allow us to perform authenticity studies or contribute to the development of simple diagnostic techniques necessary for practical applied conservation [1,2]. The analytical methods used in this field of research are identical with those used at the cutting edge of modern science [3-22]. Techniques developed for advanced physics, chemistry and biology have a commonality of application to both ancient and modern materials, since problems encountered in both the advanced technology and cultural heritage areas are similar. However, there is one essential difference between the analysis of ancient and modern materials - an art object or ancient artefact cannot be replaced, and the consumption or damaging of even a small part of it for analytical purposes must be undertaken only where vital data cannot otherwise be obtained.

Depending on the information required, one might use a combination of truly non-invasive techniques (i.e. those which do not require a sample to be removed from the object, and which leave the object in essentially the same state before and after analysis), micro-destructive techniques (i.e. those which consume or damage a few picoliters of material and which may require the removal of a sample) and non-destructive techniques (i.e. a sample or complete object can be re-analyzed (with another technique) for further examination). The distinction between these techniques and types of analyses is of particular importance in the conservation field. Nevertheless research scientists generally use the term "non-destructive" for any of the above-mentioned analysis methods [23]. In all cases, however, one should aim at the maximization of information and the minimization of the consumed volume.

This paper gives an overview of research in or associated with the pan-European network COST Action G8. COST is an EU initiative that allows the coordination of nationally funded research at a pan-European level and its activities are based on so-called actions which are networks on a specific topic covering basic and pre-competitive research. Action G8 is one of these networks and has 24 member countries. Its first goal aims at achieving a better preservation and conservation of our cultural heritage by increasing the knowledge in art and archaeological objects through chemical and physical analyses [2]. Furthermore Action G8 aims at creating a Europe-wide environment, in which people directly concerned with the maintenance of our cultural heritage (i.e. art historians, archaeologists, conservators and curators) and analytical scientists (i.e. physicists, chemists, material scientists, geologists, etc.) can exchange knowledge. The multidisciplinary community of action is essential as in the current economic climate it is extremely difficult for museums to develop new analytical methods or techniques. The need for collaboration with experts in state-of-the art analytical instrumentation is therefore very high and can tap-in to sources of knowledge and sophistication of equipment, which would otherwise be impossible in the small conservation and science groups in museums.

In what follows the examples of research activities have been classified according to the type of material studied. Reading through the various examples, it should be kept in mind that in general the solution to any cultural heritage problem rarely depends on the application of a single technique, even though it may not be always explicitly mentioned. In addition there are many other analytical techniques commonly used in the field, which are not mentioned here.

\section{Painted works of art}

Paintings, frescoes, miniatures and illuminated manuscripts are an inherent part of our cultural heritage. The pigments used in these objects, including their spatial distribution, are characteristic for the period in which the art object was made, their provenance and, in a most of the cases, the individual artist. Microscopic and molecular information about the nature and the distribution of pigments can therefore contribute to the answering of technical art historical questions, such as the deduction of the original appearance of the object, painting techniques, authenticity and the establishment of the chemical and physical conditions before conservation and restoration [24]. The latter is necessary, especially when deciding upon correct treatment methods to conserve or restore the artifacts.

Several elemental analytical methods are currently exploited for the analysis of painted works of art, including X-ray fluorescence (XRF) and particle induced X-ray analysis (PIXE), while methods, such as Raman, infrared (IR), X-ray diffraction (XRD) and static secondary ion mass spectrometry (SSIMS) can deliver specific molecular information. The latter is especially useful in the analysis of paint layers which are applied on top of each other or when a single paint layer contains several pigments.

The fact that analyses need to be done in a non-destructive and even more so in a non-invasive manner is extremely important here as removing samples is in most cases unacceptable. In that regard it is not surprising that XRF is an extensively applied technique in this field of analysis. For example Sközefalvi-Nagy et al. describe the use of titanium elemental mapping of white spots on paintings to date or authenticate the painting [25]. Analyses were performed by laying the paintings horizontally and positioning the X-ray beam by help of a removable "aiming pin". The method is based on the fact that titanium dioxide white $\left(\mathrm{TiO}_{2}\right)$ has only been available since 1920. However the decision is not always 
as simple since there are other frequently used white pigments such as barite $\left(\mathrm{BaSO}_{4}\right)$, zinc white $(\mathrm{ZnO})$ or chalk $\left(\mathrm{CaCO}_{3}\right)$.

By making use of X-ray optics, it is possible to focus an $\mathrm{X}$ ray beam down to a spot size in the order of 10 s of microns, thereby allowing spatially resolved XRF measurements. The technique called micro X-ray fluorescence analysis ( $\mu$-XRF) has been developed very rapidly in the past 10 years and is nowadays a well established analytical method allowing 2D elemental mapping or line-scanning on the various surfaces of painted works of art [26-33]. Kanngiesser et al. recently improved the capabilities of the $\mu$-XRF method further towards a three dimensional (3D) $\mu$-XRF by realizing a confocal X-ray set-up and applied it to the $3 \mathrm{D}$ investigation of paint layers allowing a more complete analysis [34,35].

Also synchrotron radiation XRF (SR-XRF) has started to play an increasingly important part in pigment and paint layer analyses [15]. The specific features of synchrotron radiation include energy tunability, higher photon flux, and a higher resolution. Another major advantage is the application of synchrotron $\mu$-beam XRF in order to identify selectively areas of analyses. In a study by Reiche et al. [36] the authors use spatially dissolved SR-XRF to investigate Renaissance silverpoint drawings from Albrecht Dürer (1520) and compare the results obtained with analyses previously performed using PIXE. Šmit et al. [37], on the other hand, used SR-XRF in a confocal setup for the depth analysis of paint layers of 16 th century oil paintings. The authors were able to characterize the various layers with a spatial resolution of $30 \mu \mathrm{m}$.

External beam PIXE has for quite some time been a very popular tool for the identification of pigments. In this setup one extracts the beam out to atmosphere, where the target is hit by the beam and can be therefore analyzed with no need of placing it in vacuum. Due to the high sensitivity of PIXE it is possible to obtain extended information on materials with very low beam current, which has as result that the analysis does not produce any visible effect to the work [12]. At the Louvre it has been for more than 15 years a standard analysis technique [11]. As an example, Duval et al. [38] analyzed more than 70 metal point drawings by Italian, Flemish and German artists using external PIXE. The latter is quite a challenge due the extremely small quantity of metal point marks in comparison to the substrate (paper or parchment). Other research groups use the method as well for example for the analysis of historical documents [39] and (mural) paintings [33,40-44].

By no means all pigments can be classified by elemental analysis especially when dealing with pigments which contain the same elements but have a different chemical formula. In this regard obtaining molecular information of the compounds becomes crucial. The latter refers to specification of the local composition of a sample in terms of molecules rather than elements. Depending on the analytical methodology used, the oxidation state of an element, the presence of specific bonds, or the entire molecule as a whole is characterized. In a study by Hochleitner et al. [45] the combination of XRF and XRD was used to establish a database of commonly used inorganic pigments. Analyses were performed on commercially available powder samples. Results showed that the combination of both methods enhanced significantly the potential for obtaining results as most of the pigments could be distinguished by their phases. Here, in a similar way to XRF, synchrotron radiation $\mathrm{X}$-ray diffraction (SR-XRD) is rapidly gaining interest in the field. In a study by Dooryhee et al., for example [46], SR-XRD is used to examine the pigments of a Roman wall painting. The joined elemental and mineral maps are able to mimic the major features of the painting. Moreover, different structural phases made of common atomic elements are differentiated and the textures and graininess can be measured and related to the artist's know-how.

Raman microscopy has perhaps emerged as the most widely used molecular technique for pigment studies [16]. In a similar way to XRF equipment, instrumental developments have led lately to the availability of $\mu$-Raman instruments. Kendix et al. [47] used such instrument for the study of architectural paint to date wall paint from the "Landhaus Bauer", a country house in Hamburg created by the Danish neo-classical architect C.F. Hansen. The results were compared with traditional XRD techniques and show a good agreement. Other studies including $\mu$-Raman include the analyses of mural paintings $[33,48-50]$, paintings [51-53] and drawings [54-56]. The past few years, also mobile fiber-optic-based Raman instruments have been available on the market. They offer a means to avoid destructive sampling and eliminate the need to transport artifacts for spectrochemical analysis [57].

Although it is not a very common technique in the identification of pigments, one of the major advantages of static secondary ion mass spectrometry resides in its ability to characterize and image both inorganic and organic analytes, thereby representing one of the few methods of closing the traditional gap between the fields of organic and inorganic analytical chemistry. This capability has been demonstrated in work by the research group at AMOLF [58-62] for the study of paint cross sections. As an example Keune and Boon [61] studied a cross section taken from the red dress in "the triumphal Procession with Sacrifacial Bull" (Oranjezaal, Huis Ten Bosch Palace, the Hague, the Netherlands)) by P. De Grebber (1650). The color of this dress should have been vivid red, but is transformed into greyish strokes (Fig. 1), which indicate the blackening of vermilion ( $\mathrm{HgS}$, trigonal), a lightinduced degradation phenomenon. The composition of the black product has been debated and the aim of the study was to verify the product and to provide new insights into the blackening mechanism. SIMS spectra were acquired in the negative ion mode. Chloride and sulphide dominate in the spectra. Their spatial distribution is plotted in Fig. 2. Fig. 2A represents the light microscopic image of the scanned SIMS area, showing the degraded layer on top and a few intact vermilion particles deeper down. The intact red vermilion particles contain sulfide and chloride. The chloride is present in higher amounts in the degraded layer and corresponds to the black and white particles. Line scans drawn from the top to the bottom of the layer (see white arrows in Fig. $2 \mathrm{~A}-\mathrm{C}$ ) visualize the distribution of the secondary ion yields. The secondary ion yields of both chloride and sulphide ions are depicted in Fig. 2D-E. 


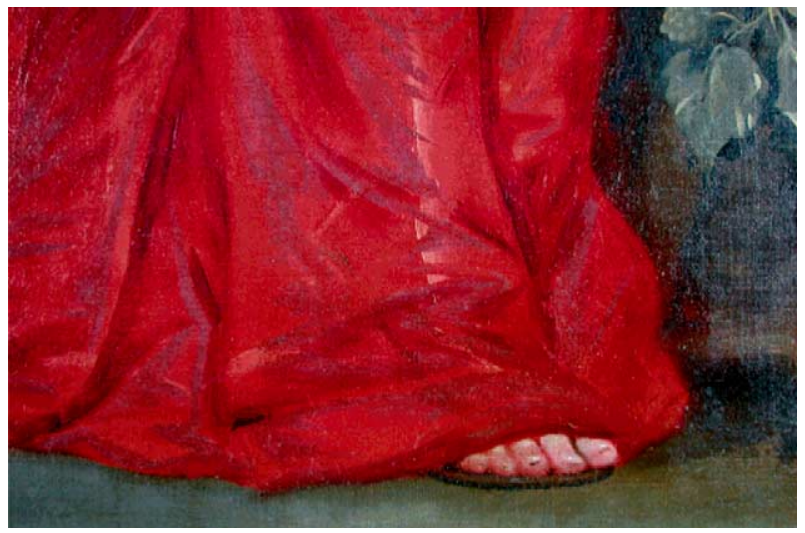

Fig. 1. Detail of "Triumphal Procession with Sacrificial Bull" by P. de Grebber (1650) (Oranjezaal, Huis Ten Bosch Palace, The Hague, The Netherlands) showing grayish strokes on top of the red dress. These highlights consist of blackened vermilion. Photo: L. Speleers, Stichting Restauratie Atelier Limburg (SRAL), Maastricht, The Netherlands. After [61].
The images also indicate the possibility of obtaining molecule specific information. SSIMS has in this regard emerged as a promising technique when it comes to obtaining molecule specific information $[63,64]$. Its potential advantage here lies primarily in the use of a low flux ion bombardment resulting negligible cumulative damage so that molecular structure survives intact on the surface and the molecular ions are representative of the surface composition. In a feasibility study by Van Ham et al. [65] the possibilities of static SIMS were explored to characterize pure inorganic pigments used in paintings by means of molecular information. The study showed amongst others the possibility to differentiate verdigris, a copper acetate $\left(\left(\mathrm{CH}_{3} \mathrm{COO}\right)_{2} \mathrm{Cu}\right.$. $\left.2 \mathrm{Cu}(\mathrm{OH})_{2}\right)$ from another commonly used green pigment, malachite, a copper carbonate $\left(\mathrm{CuCO}_{3} \cdot \mathrm{Cu}(\mathrm{OH})_{2}\right)$, both pigments which contain the same elements but have a different chemical formula.

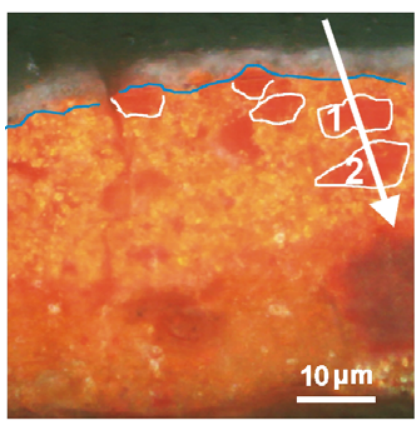

A

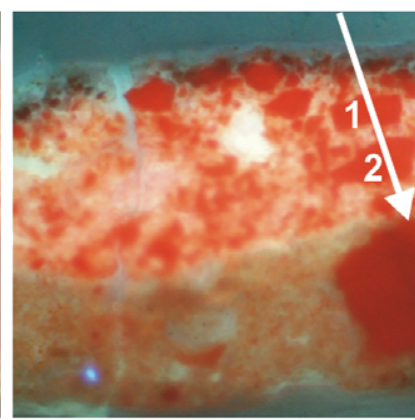

B

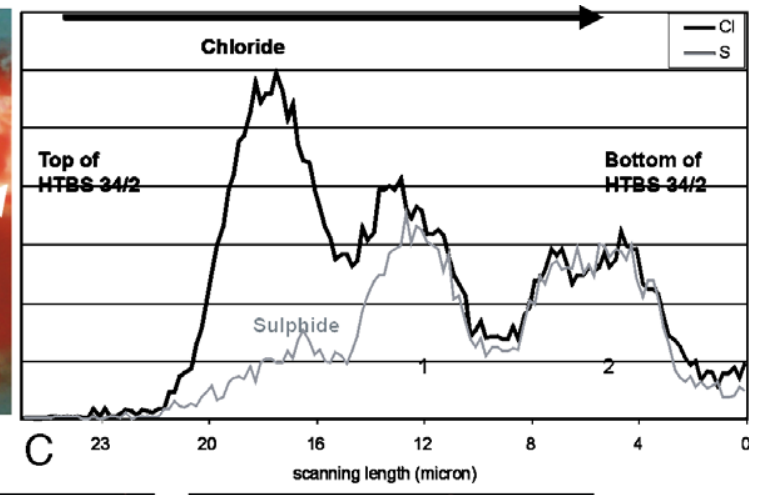

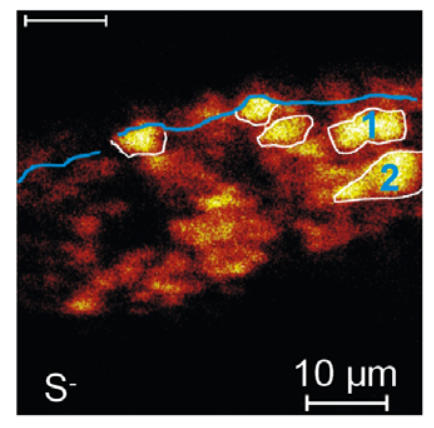

D

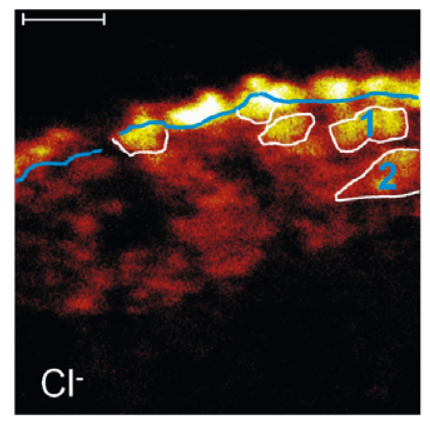

E

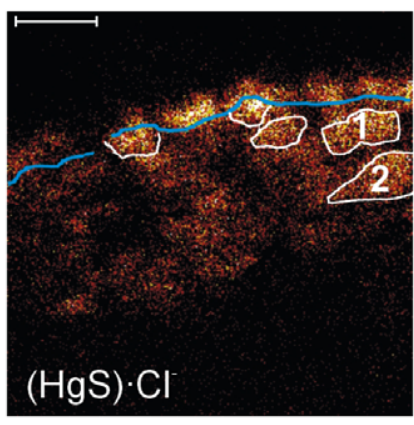

$\mathrm{F}$

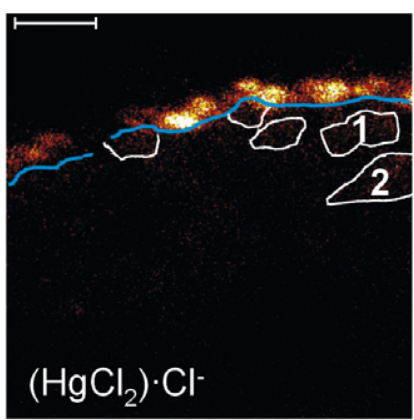

$\mathrm{G}$

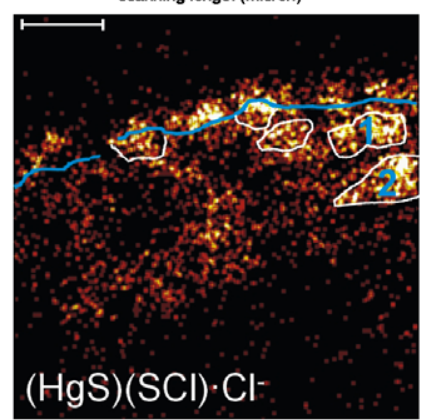

$\mathrm{H}$

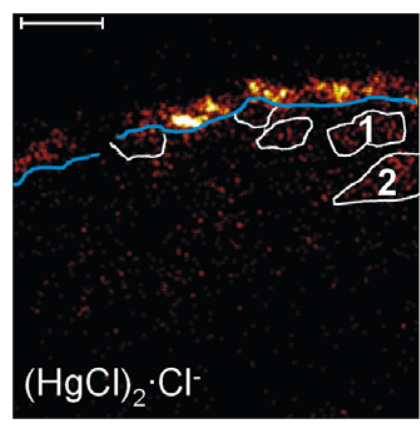

I

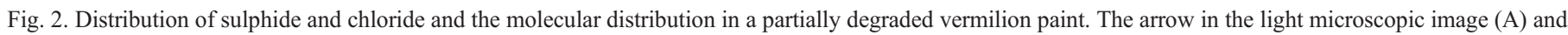

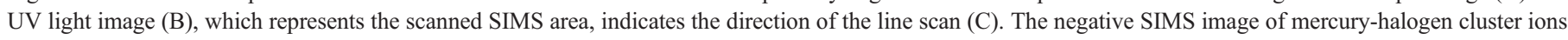

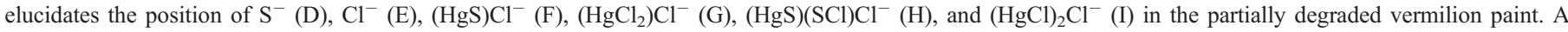

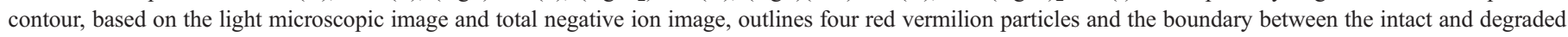
paint. After Ref. [61]. 
Speciation can also be performed on the level of images, not only spectra. Returning to the example of the red dress, SIMS images in Fig. 2F-I illustrate the distribution of the adduct ions form $\mathrm{HgS}_{n}\left[\left(\mathrm{HgS} \mathrm{Cl}^{-}\right],(\mathrm{HgS})_{n}(\mathrm{SCl})\left[(\mathrm{HgS})(\mathrm{SCl}) \mathrm{Cl}^{-}\right], \mathrm{HgCl}_{2}\right.$ $\left[\left(\mathrm{HgCl}_{2}\right) \mathrm{Cl}^{-}\right]$, and $\mathrm{HgCl}_{2}\left[(\mathrm{HgCl})_{2} \mathrm{Cl}^{-}\right]$. A contour drawn on the basis of the light microscopic image and the total negative ion image outlines five red vermilion particles and the boundary in blue between the intact and degraded paint. The results demonstrate that only mercuric chloride is to be found in the degraded paint layer [61].

\section{Textiles}

Research activities on textiles within COST Action G8 have mainly been focused on the study of fragments found in the Qumran caves in the Dead Sea region. The fragments are remains of wrappings that were used to cover the Dead Sea scrolls, which were stored in ceramic jars. Fig. 3 shows a view of Caves 4 and 5 at Qumran wherein more than 500 scrolls were found. A typical scroll jar is shown in Fig. 4.

The aim of analyzing the fragments was twofold. Firstly the goal was to establish a link between jars and scrolls by determining the age of the wrappings that were used to cover the scrolls, and to cross date it with the age of the jars, as well as with other organic material found in the settlement. Analyses were done using accelerator mass spectrometry for $\mathrm{C}^{14}$ dating [66].

Secondly it was aimed at determining the type of fibers in order to relate this information to the archaeological questions surrounding the mysterious Essenes, members of an eclectic religious sect, who are reported to have lived there 2100 years ago. This identification of fiber type is important since some authors suggest that the textile fragments are later than $68 \mathrm{AD}$ when the site of Qumran was destroyed [67]. Fig. 5 shows photographs of four textile fragments. In a joint study, the fibers were identified as linen, wool, ramie and cotton using SR-XRD. The non-destructive technique of X-ray microbeam diffraction has been demonstrated to have a number of advantages over commonly used microscopic techniques and

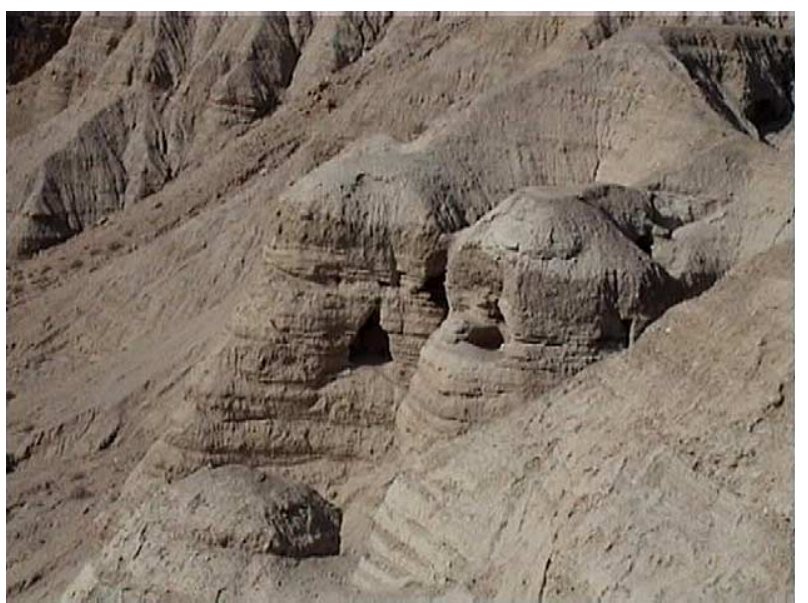

Fig. 3. A view of Caves 4 and 5 wherein more than 500 scrolls have been found. After Ref. [69].

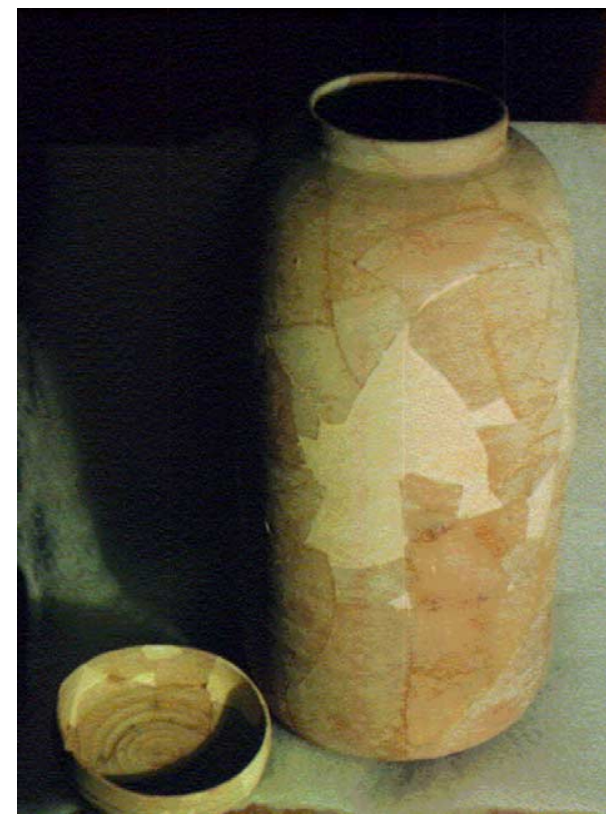

Fig. 4. A typical scroll jar. After Ref. [69].

standard XRD, including the requirement of only single fibers (a few micrometers in diameter), the direct measurement of the characteristic orientation distribution of cellulose in different plant fibers, and possibility of using high spatial resolution which enables one to collect diffraction data that are only minimally influenced by small adhering soil particles.

\section{Ceramics and glazes}

\subsection{Origin and provenance}

Provenance studies involve characterizing and locating the natural sources of the raw materials used to make artefacts, therefore contributing to the establishment of patterns of raw material procurement, trade or exchange. Besides using stylistic arguments, provenancing of artefacts is usually done in two ways. One way is by comparing the composition of the artefact to resources (i.e. raw materials or artefacts) with a known origin. Alternatively the composition of the artefact can be compared to that of a control group of artefacts of which the origin is already established. In the case of ceramics, either the chemical or the mineralogical composition can be compared with the geological source. Chemical characterization mainly implies determining trace elements, as their presence and quantity in particular are usually very specific for a given geological origin of the raw materials. Commonly used techniques for trace element analysis in ceramics include neutron activation analysis (NAA), inductively coupled plasma mass spectrometry (ICP-MS) and X-ray fluorescence spectrometry (XRF). When the mineralogical composition is to be compared, petrological data need to be obtained which relate a ceramic fabric to its geological source. Here, in general, the standard petrological approach remains the preferred technique to be used: thin sectioning provides information on the mineralogy of the pottery's non-plastic inclusions, which can 


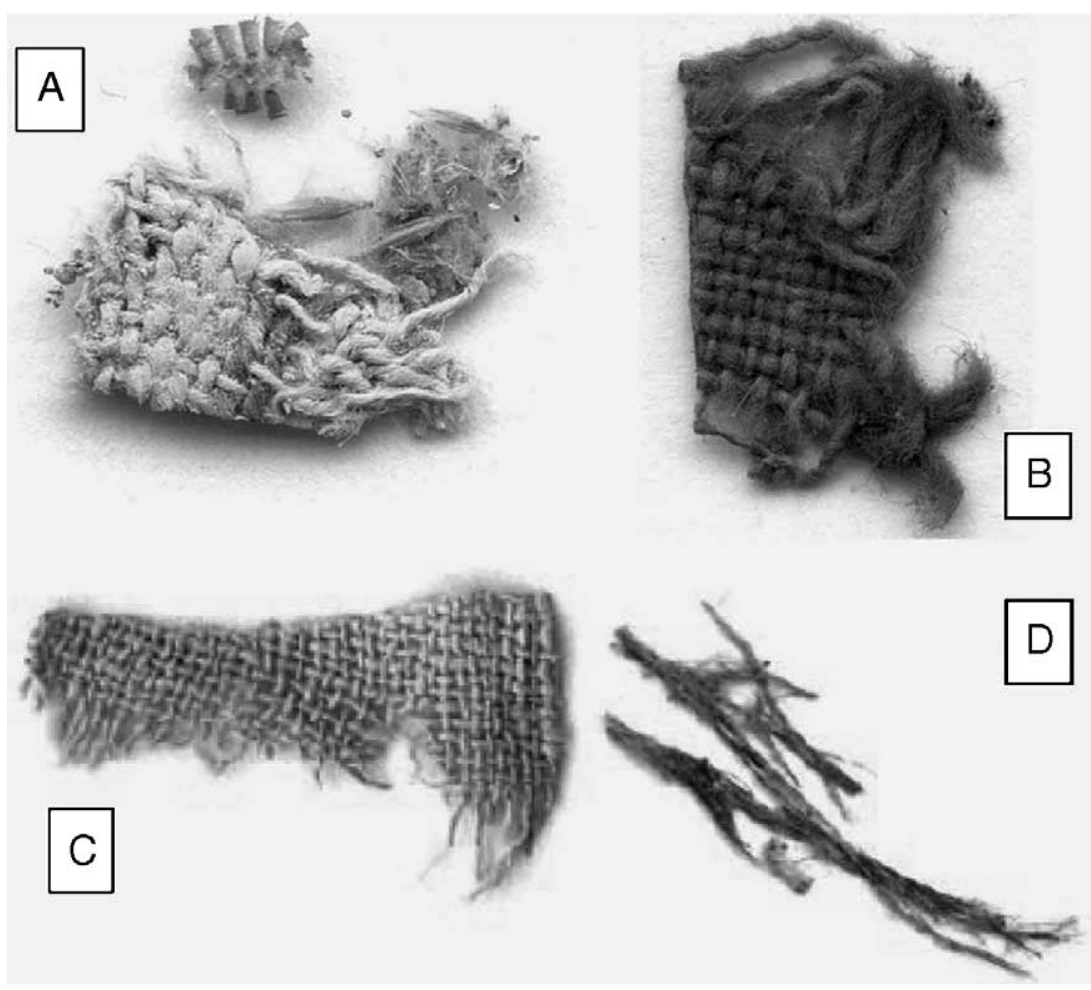

Fig. 5. Photographs of the four textile fragments from the Qumran site. (A) QUM 510, (B) QUM 525, (C) QUM 512, (D) QUM 502. After Ref. [67].

be very characteristic for a certain ware and place of origin. Nevertheless other techniques, such as SEM-EDX, provide useful supplementary information, such as the identification of unknown minerals, very small minerals or minerals with ambiguous optical properties [68].

Pottery provenance studies have been performed at Qumran in the Dead Sea Region [69]. About one hundred scroll jars (see also Textiles section) have been found in the Qumran caves 1-11, with the exception of caves 5 and 9. Their particular shape made it possible to carry them around in two hands, the jar pressed against the body (Fig. 4). Therefore it was thought that the jars served a double purpose, namely that of carrying the scrolls from a spot to another, as well as storing scrolls in the caves. The authors reasoned that by determining the chemical composition of the scroll jars, one would be able to trace the provenance of the scrolls. In other words when one is able to obtain a chemical composition of these jars that matches the local chemical fingerprint for Qumran alone, this would mean that the jars were made in Qumran for scrolls that probably were in the Qumran Building complex. If the chemical profile of the scroll jars on the other hand does not match statistically the local reference of Qumran, but is similar to a ceramic reference at another site, it not only proves that the jars were produced in these sites in question, but that also the scrolls that came in them were probably written or used in those sites before ending up at Qumran, because why would one produce a scroll jar in a remote site if not to carry or store scrolls to and at Qumran? A total of two hundred and twenty-six samples of pottery were analyzed by NAA. Results of this research have shown that the scroll jars can be traced to
Qumran itself, as well as to Hebron, Jericho and Beer ShebaArad. Most of the jars came from Hebron and Qumran, whereas only two jars were traceable to Jericho and one to Beer Sheba-Arad. It must be emphasized that the two Jericho "scroll" jars are also different in shape from the other jars, and one wonders whether these were used for shipping the scrolls [70].

\subsection{Techniques of manufacture and authentication}

Technological studies involve the identification of the materials and production techniques used. The information sought in answering questions with regard to technology very much depends on the type of material that is being studied. For ceramics main objectives include the identification of the mineralogy of the body, which is the clay part of the ceramic (as opposed to slips and glazes), the resources and techniques used for surface coatings (slips, paints, glazes. . .) and the firing technology [68]. In what follows a few examples will be elaborated.

Within the framework of a technological and socioeconomical study of pottery production in Tell Beydar (NE Syria) during the third millennium BC, the chemical composition and mineralogy of various ceramics from that site were studied. The data obtained was used to make inferences concerning the pottery's technology including clay preparation and firing techniques [71-73]. Three types of pottery have been found at the site: standard ware (or common ware) which is the main group of excavated pottery, cooking ware and metallic ware. With the aim of shedding new light on the still poorly understood North-Mesopotamian metallic ware (Fig. 6), 


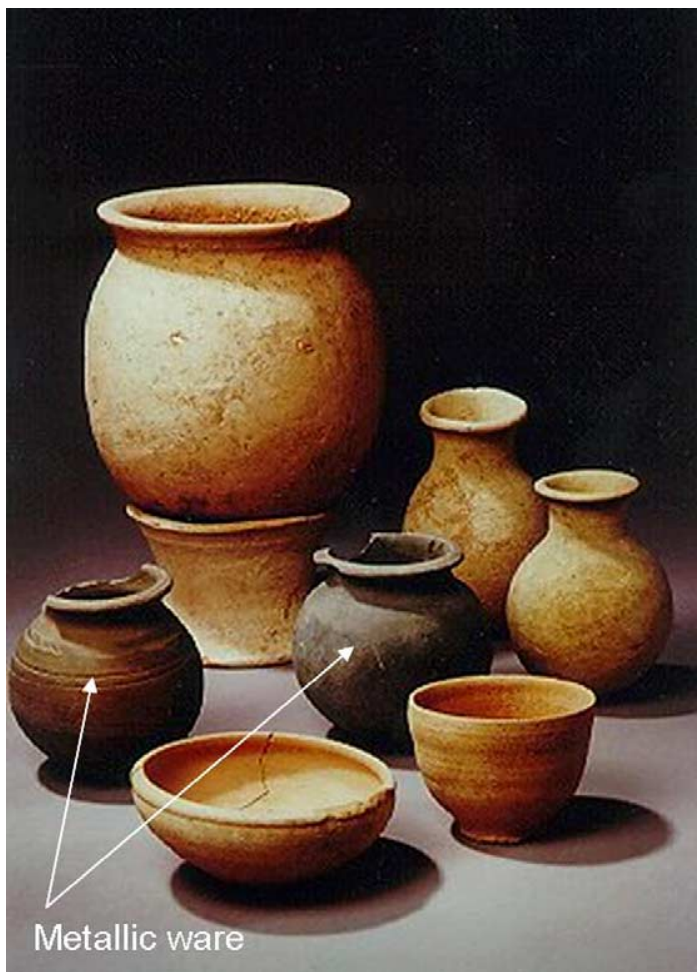

Fig. 6. Metallic ware jars (indicated with arrows) from Tell Beydar surrounded by contemporary standard ware. Reproduced with permission from Brepols Publisher.

ceramic and soil samples from Tell Beydar (NE-Syria, 3rd millennium BC) were investigated using optical microscopy, SEM-EDX and SR-XRD [72]. 'Typical' metallic ware is generally made using very dense clay, free of large inclusions. The vessel color is determined by the prevailing firing atmosphere. Very often, it is grey as a result of a reducing atmosphere, but it can also be reddish brown to orange when fired in an oxidizing atmosphere, or even a combination of these colors. As one of the more exclusive wares of its time, metallic ware usually does not constitute more than $5 \%$ of the total ceramic assemblage of the sites where it is found. The study had three aims. First, the authors wanted to elaborate the existing differentiation of non-calcareous from calcareous metallic ware in the field, without the aid of chemical analyses. Second, they wanted to define which groups of metallic ware are represented at Tell Beydar. Finally, they wanted to understand the relationship between calcareous metallic ware and standard ware. The cooking pottery was analyzed as well in an attempt to assess to what extent third millennium BC cooking pots from Upper Mesopotamia correspond to this image of the 'typical' or 'ideal' cooking pot, which could be confirmed [71].

Medieval luster ceramics, showing a golden or coppery metallic shine which sometimes exhibit purple and blue iridescence, were studied by Pradell et al. [74,75]. The origin of this decoration goes back to early Islamic times, i.e., the 10th century AD, and followed the expansion of the Arabian culture through Spain and the rest of the western Mediterranean. Luster is produced by direct application of a raw paint over a glazed ceramic (a tin-opacified high-lead, alkaline, or mixed glaze), which when fired in a reducing atmosphere results in the formation of a metallic-like layer. After firing, the remaining paint (called cosela) is removed revealing the luster beneath. In order to gain some new insight into the mechanisms involved in luster formation, the authors have reproduced some luster decorations by following the same procedures described in ancient documentation and following the surviving tradition in the Valencia area. Chemical characterization of the samples was performed using SEM-EDX, TEM and X-ray absorption spectroscopy (XAS) [74]. The experimental data showed that luster is a "new" metal glassy composite layer formed through the interaction of the raw powdered luster pigments and the glaze during firing. In a related study the role of cinnabar in the luster production was investigated. Ancient documentation referring to the use of cinnabar in the production of luster decorations has recently been corroborated by archaeological findings. However, luster decorations do not show any trace of the use of cinnabar in their composition because the temperatures involved in luster firing $\left(500-600{ }^{\circ} \mathrm{C}\right)$ result in the complete decomposition and volatilization of cinnabar. An in situ X-ray diffraction experiment was designed to clarify the role of cinnabar in the production of luster decorations [75]. It acts as a reducing agent for copper and gives a sulphur-rich environment that results in the formation of $\mathrm{Cu}^{+}$and $\mathrm{Ag}^{+}$sulphur-containing phases between 500 and $600{ }^{\circ} \mathrm{C}$. Finally, it inhibits the crystallization of silver metal in this range of temperatures.

A group of Italian glazed terracotta sculptures, attributed to the della Robbia workshop of Florence and displayed in the Louvre Museum, was analyzed in a sequence of studies by Zucchiatti et al. [76,77]. The aim of the project was to address the question of the homogeneity of these works by looking at the chemical composition of the materials, to obtain more information on the way in which the objects were manufactured and to try and reconstruct their conservation history. Both the glazes as well as the ceramic bodies were analyzed using a variety of analytical techniques such as PIXE, SEM and inductively coupled plasma atomic emission spectroscopy (ICP-AES). Results from the glazes showed a subdivision of the sculptures according to their shape, featuring flying angels, seraphs and cherubs. The ceramics analyses on the other hand suggested a common origin for the clays. A subsequent study was carried out on della Robbia sculptures, which are conserved at the Museo Nazionale del Bargello in Florence [78]. PIXE and portable XRF were used to determine the arsenic concentration in the blue pigment of the glaze, which can be used as an indicator of the provenance of the raw materials.

\section{Glass}

\subsection{Origin and provenance}

The provenance of glass objects can be determined through the chemical composition, provided a compositional classification has been previously established with a significant number of well-authenticated glasses made in certain manufacturing centers or during certain historical periods [79]. 
In a study by Šmit et al. [80] the major and trace composition of a series of 16 th century glass fragments, originating from the ruins of different $15-17$ th century castle sites in the neighborhood of Ljubljana (Slovenia) were determined. The data were compared to those obtained from archaeological glass finds originating from Ljubljana, Antwerp (Belgium) and Venice (Italy). Analyses were performed using electron probe micro analysis (EPMA), PIXE, particle induced gamma ray emission (PIGE) and SR $\mu$-XRF. The contribution of PIGE was determination of $\mathrm{Na}$, $\mathrm{Mg}$ and $\mathrm{Al}$ oxides which were able to provide unambiguous characterization of the alkali and limestone component and a stable concentration evaluation algorithm relying on the normalization of all metal oxides to $100 \%$ [81]. The results demonstrated that the Slovenian castle glasses show a similar composition to the glasses of Ljubljana, and that both exhibit great resemblance to Venetian "vitrum blanchum" glass. A few vessels with too high zirconium levels suggest a nonVenetian import. The low zirconium glass is produced with the same ashes as used in Venice.

Increasing interest in iridescent Art Nouveau glass in both public and private collections, as well as the growing number of imitations of this glass requests the need for a clear classification and identification of the provenance of such objects. In a paper by Jembrih-Simburger et al. [82] it was shown that XRF combined with multivariate analysis is a very useful tool for the determination of the authenticity and provenance of Art Nouveau iridescent glass as well as of modern glass artefacts. Schultheis et al. [83] studied iridescent Art Nouveau lead crystal glass using laser ablation inductively coupled plasma mass spectrometry (LA-ICP-MS). The authors were able to show through the analysis of lead isotopes that the fragments originate from different sources.

\subsection{Techniques of manufacture and authenticity}

If a painting is applied to the back of a glass sheet, the glass acts both as protective coating as well as the picture carrier. This gives colors an inimitable and nearly mystic glamour. Thus, simple glass panels are transformed into luminous pictures [84]. In comparison to conventional painting, the technique of reverse painting on glass differs completely. Motifs must be arranged in reversed image. The painter starts setting accents and lights with shadows alongside. Backgrounds are painted on in the last work step. A study by Neelmeijer and Mäder [84] demonstrates the profit of simultaneous measurements using the well-established methods of ion beam analysis, including PIXE, PIGE and Rutherford backscattering (RBS). Results have shown that PIXE allows a quick survey on the present inorganic pigment components, while simultaneous RBS informs on preferable localization of carbon and oxygen from binders and organic pigments. In addition, it assists in the attribution of arrangements of thin painted multi-layers. PIGE and PIXE spectra taken simultaneously from the pure glass panel inform on the state of near-surface glass preservation as well as the individual glass type used [84].

\subsection{Deterioration}

Deterioration of glass includes both chemical and structural changes. The initial stage of attack is a process that involves ion exchange between the alkali ions, which are present in the silicate structure of the glass, such as $\mathrm{Na}, \mathrm{K}$, and hydrogen from the environment. This leads to the formation of a leached or so-called "gel layer" in which alkaline elements are depleted. Provided that the glass is in continuous contact with water, the attack will eventually lead to a complete breakdown of the silicate structure. In case of atmospheric attack, the leached ions will interact with components from the ambient atmosphere such as carbon dioxide and sulfur dioxide which will lead to a crust formation including products such a calcite $\left(\mathrm{CaCO}_{3}\right)$ and gypsum $\left(\mathrm{CaSO}_{4} \cdot 2 \mathrm{H}_{2} \mathrm{O}\right)$ [85] (Fig. 7).

The initiation and progression of such deterioration are predetermined by the chemical composition of the glass and the previous degradation of the surface but also by the environmental conditions. The future state of preservation, in particular for glass of corrosion-sensitive composition, will depend on the individual storage conditions, i.e. the humidity and the temperature as well as the concentration of air pollutants. In a study by Mäder and Neelmeijer [86,87] a general recipe for non-destructive classification of glasses including the early detection of endangered glass objects is given. The objective of the paper included a correct quantification of the original glass composition, represented by the constituents of the glass bulk, despite of a thin leached surface region. Simultaneous PIGE and PIXE measurement and the comparison of their results for the element silicon are used to identify an altered region on the glass surface. If the glass is not corrosion-affected the combination of PIGE and PIXE allows one to determine the full composition correctly, i.e. the concentrations of all chemical constituents of the glass. Otherwise, the different information depths of both techniques make it possible to estimate the thickness of a thin corrosion layer. Simultaneous RBS studies are helpful in identifying more extended corrosion layers. Moreover, RBS reveals easily surface elements of

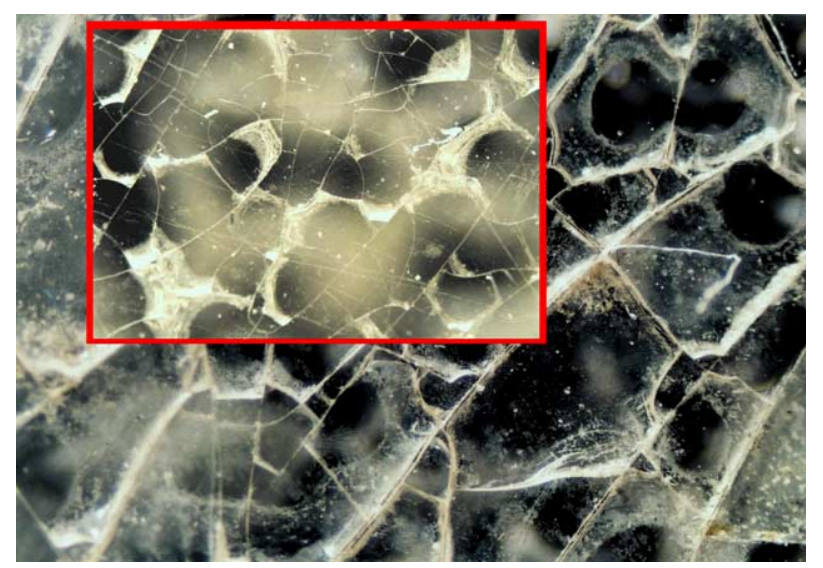

Fig. 7. Top view of a damaged glass surface viewed by scanning electron microscopy (SEM). After initial leaching, the environmental humidity creates a fine net of cracks. If therein the humid ambience penetrates deeper, flakes are formed which fall off later on due to mechanical stress. After Ref. [87]. 
higher atomic number used sometimes for special visual effects.

\section{Metals}

When surveying the metal contributions in the literature, three main topics spring forward: (1) corrosion studies, (2) technology and authenticity studies and (3) origin and provenance studies.

\subsection{Corrosion}

Simply stated, metal corrosion is a process of chemical dissolution. Cations migrate from the metal substrate and react with available anions to form the metal salts that constitute tarnish layers and corrosion crusts. The character and chemical makeup of the corrosion products depend on the nature of the substrate and the environment to which it is exposed. Analyses are necessary to study the alterations imposed on an artifact in order to contribute to the development of adequate conservation and restoration treatments.

De Ryck et al. [88] investigated commonly used techniques for corrosion research, such as optical microscopy and SEMEDX, in combination with techniques capable of molecular speciation, such as time-of-flight secondary ion mass spectrometry (TOFSIMS), synchrotron radiation FTIR (SR-FTIR), synchrotron radiation XRD (SR-XRD) and X-ray absorption near edge structure (XANES) spectroscopy. The aim was to find a suitable combination of techniques for a complete characterization of the corrosion compounds both at an elemental and molecular level with specific emphasis on their spatial distribution. Results have shown that the combination of optical microscopy, SEM-EDX and SR-XRD give the best results for the characterization of corrosion layers on ancient metal objects. The latter is valid for corrosion layers with thicknesses in the order of microns or more. However when corrosion layers are much thinner, as may be the case for silver or when one is interested in studying the initial stage of corrosion, a different analytical technique is required to access the top surface regions of the artefact. In this regard Dowsett et al. [89] have successfully used ultra-low-energy dynamic secondary ion mass spectrometry (uleSIMS) in a study of tarnished museum silver. The method is micro-destructive, but has a sensitivity typically better than 1 atom in $10^{6}$. It can provide an analysis within the top nanometers, or the top few micrometers of a surface, and gives chemical fingerprinting as well as atomic composition information.

When it comes to preventing further deterioration of metal objects special treatments are required. Archaeological alloys recovered from wet and salty environments for example should not be exposed directly to the atmosphere as the metal usually corrodes at an accelerated rate in the oxygen-rich air [90]. Therefore storage and stabilization treatments of the objects are usually carried out in aqueous solutions. Leyssens et al. [91,92] have investigated whether corrosion potential measurements (Ecorr) can provide useful information on the effectiveness of the currently used stabilization and storage treatments. Results in the past have shown certain instability of the artifacts during their storage, including the transformation of natural patina and the development of active corrosion $[93,94]$. The hypothesis behind the Ecorr monitoring method is that if the corrosion potential does not change as a function of time, the surface composition should be stable. The project aims at giving a simple early warning system so that conservators can monitor the treatment of copper artefacts in aqueous solution. Evaluating the corrosion potential method was done by performing SR-XRD measurements of the surface at regular intervals. The latter however dictates that the samples under investigation need to be transferred out of their solution and potential environment and sometimes into vacuum. This environmental change will almost certainly alter the surface. The study was therefore in a second stage improved with the development of a novel electrochemical cell which is designed for in situ, time resolved XRD studies [95]. In situ techniques bring a significant extra contribution to the understanding of surface reactions at electrodes, as they do not require an electrode transfer outside the cell. Most importantly, it becomes possible to characterize the surface using electrochemical techniques in parallel with XRD, XAS or other analytical techniques. All of these aspects are crucial to the interpretation of time dependent surface reactions. A preliminary evaluation of the cell was done with a set of artificially corroded copper electrodes [96].

\subsection{Technology and authenticity}

A large fraction of the work related to technology and authenticity of metal objects has been dedicated to coins. For most of recorded history money coins have been the medium of exchange. They therefore represent important objects of our cultural heritage.

In a study by Constantinescu et al. [97] the authors focus their attention on thassos silver tetradrachmae and ApolloniaDyrrhachium silver drachmae emitted by these Greek cities under Pompejus authority during the First Roman Civil War. The analyzed coins were found on the territory of present Romania (ancient Dacia). The important presence of Apollonia-Dyrrhachium drachmae on this site can be explained by the hypothesis that these coins were probably used by Pompejus as payment for Dacian mercenaries. The authors used a ${ }^{241} \mathrm{Am}$ gamma source based X-ray fluorescence and in vacuum $3 \mathrm{MeV}$ protons particle induced X-ray emission. The study allowed a classification of the coins and connections between the coins composition and historical aspects of the corresponding minting period could be drawn.

Another set of silver coins, this time "Friesacher Pfennig" and "Tiroler Kreuzer" were analyzed by Linke et al. [98]. Using XRF, the authors were able to determine the trace elements of the coins and as a result were able to assign the various coins to their mint.

High energy (68 MeV) PIXE was used to study a collection of "Wienner Pfennig", which is a special type of Medieval silver coin. The goal was to show the evolution of the copper content of the coins and the verification of the actual coin classification. The advantage of using proton energies of 68 


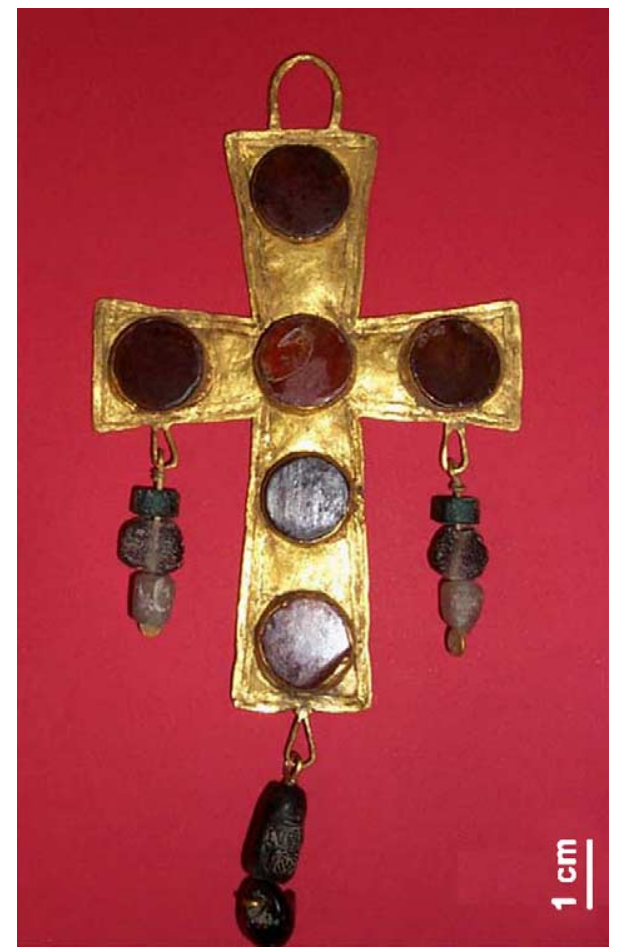

Fig. 8. Visigothic gold cross found in Jaèn, Spain, dated to the $6-7$ th century (private collection). After Ref. [104].

$\mathrm{MeV}$ is the fact that they have much a larger range, i.e. information depth, in the investigated material. In addition, the $\mathrm{X}$-ray production cross sections for the $\mathrm{K}$ lines of heavy elements $(Z>50)$ is at least a factor of 100 larger than with the more commonly used $3 \mathrm{MeV}$ protons [99]. Heavy elements may, therefore, be detected by their $\mathrm{K}$ X-rays showing also a much smaller absorption coefficient in the analyzed material than the L X-rays. The analyses were able to provide bulk information in a non-destructive manner of 550 coins. The method was compared to XRF and results showed a satisfactory agreement [100].

Apart from silver coins, gold objects have attracted quite some interest. Gold is one of the first metals used by humans and because of its great beauty it is esteemed very highly. The first gold objects manufactured in ancient times were made with native gold, while refined gold was already being obtained in the second half of the second millennium BC. In parallel with the evolution of refining and alloying technologies, the increase in the skill of goldsmiths led to the development of several other techniques such as soldering and gilding. In order to study the development of gold working one must obtain appropriate information by analyzing gold artefacts. Information can be obtained about both the manufacturing technologies used to make the objects and the provenance of the metal. Metallurgical (microstructural) or elemental composition analysis can be performed to gain complementary information on gold working [101].

The Guerrazar treasure (Toledo, Spain) and the Torredonjimeno treasure (Jaén, Spain) are both exceptional treasures of Visigothic gold jewelry. The collections consist of crosses and crown that were donated by royalty to churches in Toledo and
Seville during the 6th and 7th century AD. Various studies have dealt with the compositional and technical study of the treasures [102,103]. Ontalba Salamanca et al. [104] have recently undertaken a study of a Visigothic gold cross, found in the Jaén region, which belongs to a private collection (Fig. 8). The work therefore contributes to the extension an existing databank on Visigothic jewelry. Analyses were done using external beam PIXE. A photograph of the setup is shown in Fig. 9. Clear difference in chemical composition compared to objects found in Toledo could be established, confirming the different Visigothic workshops of the Iberian Peninsula.

In a study by Enguita et al. [105] gilded threads belonging to Spanish textile collections were analyzed using PIXE and Auger electron spectroscopy (AES) to determine the composition and structure of the threads. Knowledge of the layered structure can give very valuable information about the ancient manufacturing techniques and about the appropriate treatment for cleaning and conservation. AES in particular was used to characterize the layer structure, in spite of the fact that it is a destructive technique with the inconvenience that analyses need to be performed in ultra-high vacuum.

The metallurgy of several armour pieces dating from the 16th to 17 th century from the Palace armoury collection (Valletta, Malta) was studied using optical microscopy and metallography by Vella et al. [106]. The study was able to contribute to the knowledge of the chemical composition of the various pieces, thereby demonstrating the heterogeneity in composition, and production techniques in that period and that region.

Neutron imaging techniques are very useful methods which have not been mentioned up to now. The advantage of neutron imaging in comparison to X-ray imaging is the fact that neutrons have a much higher penetration for most of the relevant metals. It is well known that the attenuation of X-rays increases strongly with higher mass numbers of the investigated material. In material testing of samples of technical or

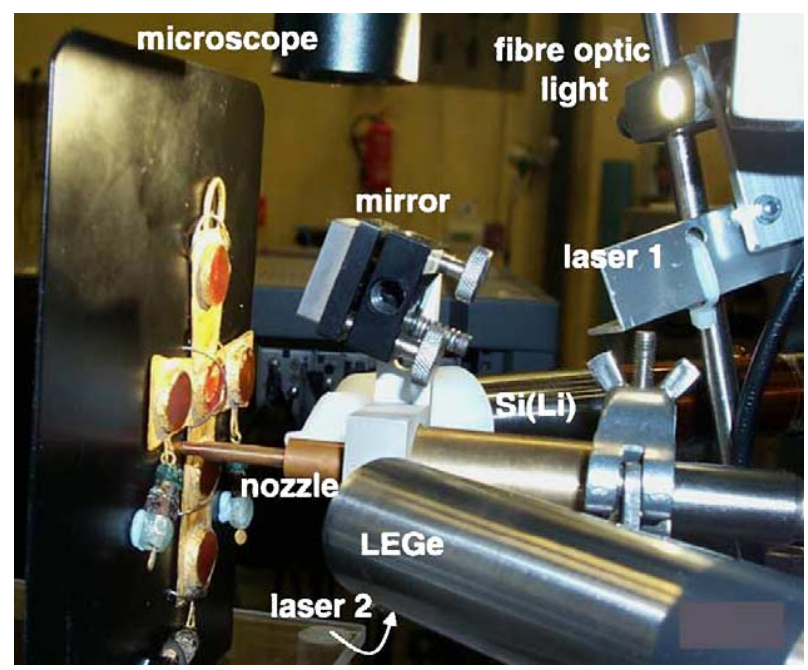

Fig. 9. Visigothic cross placed in front of the external beam system during its PIXE analysis. The system configuration is illustrated: external beam exit nozzle, X-ray detectors, two low power lasers to define the exit window-sample distance, a mirror and a CCD video microscope to visualize the irradiated area. After Ref. [104]. 

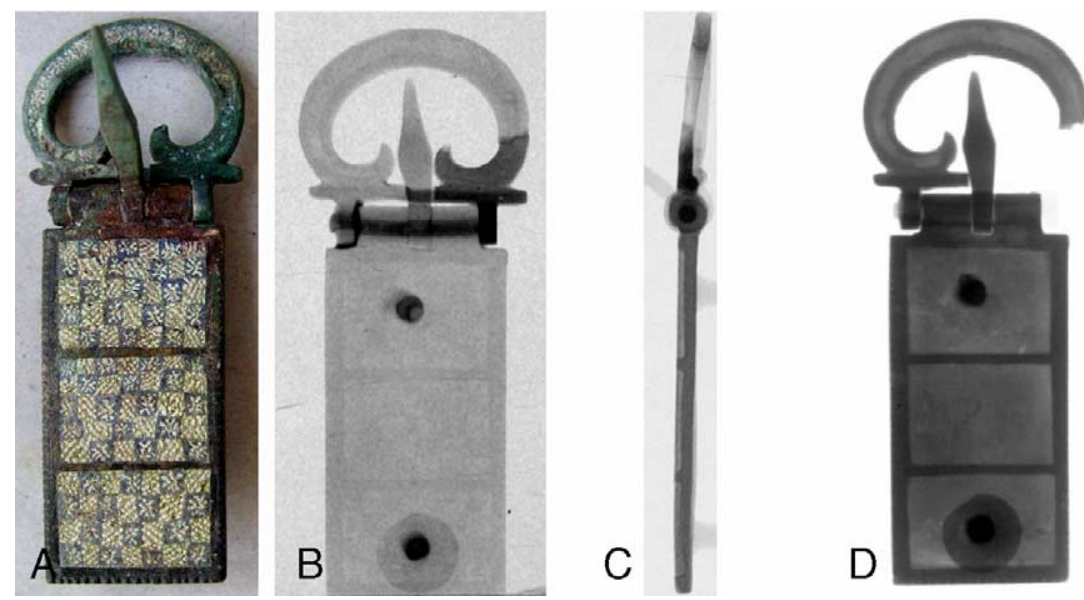

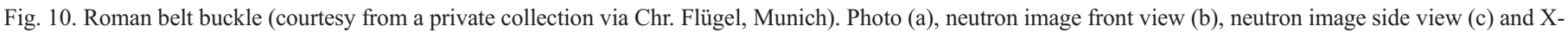
ray image (d). After Ref. [107].

technological relevance (search for defects and material changes), where mostly metals are involved, the penetration of X-rays is limited. If heavy metals are to be investigated, few $\mathrm{mm}$ are sufficient to shield the X-ray beam completely. At this point, neutrons become valuable due to higher penetration for most of the relevant metals. On the other hand the attenuation of thermal neutrons by hydrogen is much larger than for X-rays and very small layers of hydrogen containing material deliver high contrast [107]. In a collaboration between the Paul Scherrer Institute and the Swiss National museum, both in Zurich, the authors investigated various metallic object from Roman and Celtic origin [107]. The aim of their research involved the study of the interior structure of the objects, thereby obtaining information on their manufacturing process, their authenticity and potential changes applied by earlier restoration works. Fig. 10 shows an example of a Roman belt buckle which compares the capabilities of X-ray and neutron imaging. It is obvious that neutrons have a much better transmission in comparison to X-rays. Furthermore the reconstruction of parts of the buckle and of the full base rod becomes obvious due to missing such parts in the X-ray image but clear visibility in the neutron image. These parts were added to repair the belt buckle by means of a modern resin.

\subsection{Origin and provenance}

A study by Guerra [108] examined the trace elements of a collection of gold objects using PIXE, PIGE, PIXE-XRF and PAA. The capabilities and disadvantages of the various methods were compared. In addition a classification with regard to provenance could be made. Other provenance studies of gold cultural heritage objects are reported by Karydas [109], Constantinescu [110] and Bugoi [111].

\section{Conclusions}

This review does not aim to be an exhaustive summary of all the techniques which can be applied in the field of cultural heritage research.
The use of analytical techniques for cultural heritage applications is receiving an increasing amount of attention, both by analytical scientists as well as by people more directly involved with the preservation of our cultural heritage (e.g. art historians, curators, archaeologists, conservators, etc.). This is not only evidenced by the vast number of scientific papers published in the literature over the past few years, but also by the various conferences and workshops in the field.

There is no doubt that current research has strengthened the multidisciplinary community in this field. It has enhanced the capability for answering questions related to museum objects, which could not readily be solved, and the exchange of knowledge in both directions. Moreover Action G8 has provided museums and similar institutes easy access to universities and research facilities that have the required analytical techniques and related expertise available.

Nevertheless the situation is still capable of improvement. Apart from the unquestionable need to strengthen further the teamwork between the two groups of people involved in this research, one of the aims for the future could be the development of critical pathways through the various analytical techniques in order to maximize the information from minimal sample handling and consumption. In other words a synergistic combination of techniques which is matched to the problem at hand is required to advance the knowledge required to convert a decaying museum artefact into a protected and informative public display.

\section{Acknowledgements}

A special word of thanks to COST Action G8 and its members for a very fruitful and pleasant collaboration in the field of cultural heritage research.

\section{References}

[1] A. Adriaens, European actions to promote and coordinate the use of analytical techniques for cultural heritage studies, Trac, Trends Anal. Chem. 23 (8) (2004) 583-586. 
[2] A. Adriaens, G. Demortier, COST Actions G1 and G8: EU programs on the use of radiation in art and archaeometry, Nucl. Instrum. Methods B 226 (2004) 3-9.

[3] D. Creagh, D. Bradley (Eds.), Radiation in Art and Archaeometry, Elsevier Science B.V., Amsterdam, 2000.

[4] E. Ciliberto, G. Spoto (Eds.), Modern Analytical Methods in Art and Archaeology, Chemical Analysis, vol. 155, Wiley, New York, 2000.

[5] G. Demortier, A. Adriaens (Eds.), Ion Beam Study of Art and Archaeological Objects, EUR 19218, Office for the Official Publications of the European Union, Luxembourg, 2000.

[6] J. Townsend, K. Eremin, A. Adriaens (Eds.), Conservation Science 2002, Archetype Publications, London, 2003.

[7] K. Janssens, R. Van Grieken (Eds.), Non-destructive Microanalysis of Cultural Heritage Materials, Elsevier Science B.V., Amsterdam, 2004.

[8] R. Van Grieken, K. Janssens (Eds.), Cultural Heritage Conservation and Environmental Impact Assessment by Non-destructive Testing and Micro-analysis, Taylor and Francis Group plc, London, 2005.

[9] A. Adriaens, C. Degrigny, J. Cassar (Eds.), Benefits of Non-destructive Analytical Techniques for Conservation, EUR 21636, Office for the Official Publications of the European Union, Luxembourg, 2005.

[10] G. Bitossi, R. Giorgi, M. Mauro, B. Salvadori, L. Dei, Spectroscopic techniques in cultural heritage: a survey, Appl. Spectrosc. Rev. 40 (3) (2005) 187-228.

[11] J.C. Dran, J. Salomon, T. Calligaro, Ph. Walter, Ion beam analysis of art works: 14 years of use in the Louvre, Nucl. Instrum. Methods B 219220 (2004) 7-15.

[12] P.A. Mandò, Nuclear physics and archaeometry, Nucl. Phys., A 751 (2005) 393c-408c.

[13] M. Schreiner, B. Fruhmann, D. Jembrih-Simburger, R. Linke, X-rays in art and archaeology: an overview, Powder Diffr. 19 (1) (2004) 3-11.

[14] M. Milazzo, Radiation applications in art and archaeometry. X-ray fluorescence applications to archaeometry. Possibility of obtaining nondestructive quantitative analyses, Nucl. Instrum. Methods B 213 (2004) $683-692$.

[15] E. Dooryhee, P. Martinetto, Ph. Walter, M. Anne, Synchrotron X-ray analyses in art and archaeology, Rad. Phys. Chem. 71 (2004) 863-868.

[16] G.D. Smith, R.J.H. Clark, Raman spectroscopy in art history and conservation, Rev. Conserv. 2 (2001) 92-106.

[17] G.D. Smith, R.J.H. Clark, Raman microscopy in archaeological science, J. Archaeol. Sci. 31 (2004) 1137-1160.

[18] P. Vandenabeele, Raman spectroscopy in art and archaeology, J. Raman Spectrosc. 35 (2004) 607-609.

[19] G. Spoto, Secondary ion mass spectrometry in art and archaeology, Thermochim. Acta 365 (2000) 157-166.

[20] M.G. Dowsett, A. Adriaens, The role of SIMS in cultural heritage studies, Nucl. Instrum. Methods B 226 (2004) 38-52.

[21] A. Adriaens, M.G. Dowsett, Applications of SIMS to cultural heritage studies, App. Surf. Sci., in press.

[22] N. Salvadó, S. Butí, M.J. Tobin, E. Pantos, A.J.N.W. Prag, T. Pradell, Advantages of the use of SR-FT-IR microspectroscopy: applications to cultural heritage, Anal. Chem. 77 (2005) 3444-3451.

[23] J. Cassar, C. Degrigny, The philosophy of the workshop, in: A. Adriaens, C. Degrigny, J. Cassar (Eds.), Benefits of Non-destructive Analytical Techniques for Conservation, Office for the Official Publications of the European Union, Luxembourg, 2005, pp. 9-12.

[24] K. Keune, Binding Medium, Pigments and Metal Soaps Characterized and Localized in Paint Cross Sections, Dissertation, Molart report, Archetype, London, 2005.

[25] Z. Skökefalvi-Nagi, I. Demeter, A. Kocsonya, I. Kovács, Non-destructive XRF analysis of paintings, Nucl. Instrum. Methods B 226 (2004) $53-59$.

[26] O. Hahn, D. Oltrogge, H. Bevers, Coloured prints of the 16th century: non-destructive analyses on coloured engravings from Albrecht Dürer and contemporary artists, Archaeometry 46 (2) (2004) 273-282.

[27] M. Mantler, J. Klikovits, Analysis of art objects and other delicate samples: is XRF really non-destructive? Powder Diffr. 19 (1) (2004) $16-19$.
[28] T. Calligaro, J.C. Dran, M. Klein, Application of photo-detection to art and archaeology at the C2RMF, Nucl. Instrum. Methods A 504 (1-3) (2003) 213-221.

[29] M. Mantler, M. Schreiner, X-ray fluorescence spectrometry in art and archaeology, X-ray Spectrom. 29 (1) (2000) 3-17.

[30] G. Paternoster, R. Rinzivillo, F. Nunziata, E.M. Castellucci, C. Lofrumento, A. Zoppi, A.C. Felici, G. Fronterotta, C. Nicolais, M. Piacentini, S. Sciuti, M. Vendittelli, Study on the technique of the Roman age mural paintings by micro-XRF with polycapillary conic collimator and micro-Raman analyses, J. Cult. Herit. 6 (1) (2005) 21-28.

[31] K. Janssens, G. Vittiglio, I. Deraedt, A. Aerts, B. Vekemans, L. Vincze, F. Wei, I. De Ryck, O. Schalm, F. Adams, A. Rindby, A. Knochel, A. Simionovici, A. Snigirev, Use of microscopic XRF for non-destructive analysis in art and archaeometry, X-ray Spectrom. 29 (1) (2000) 73-91.

[32] F. Rosi, C. Milliani, I. Borgia, B.G. Brunetti, A. Sgamelotti, Identification of nineteenth century blue and green pigments by in-situ X-ray fluorescence and micro-Raman spectroscopy, J. Raman Spectrosc. 35 (8/9) (2004) 610-615.

[33] M.S. del Rio, P. Martinetto, A. Somogyi, C. Reyes-Valerio, E. Dooryhee, N. Peltier, L. Alianelli, B. Moignard, L. Pichon, T. Calligaro, J.C. Dran, Microanalysis study of archaeological mural samples containing maya blue pigment, Spectrochim. Acta Part B 59 (2004) 1619-1625.

[34] B. Kanngießer, W. Malzer, I. Reiche, A new 3D micro X-ray fluorescence analysis set-up-first archaeometric applications, Nucl. Instrum. Methods B. 211 (2003) 259-264.

[35] B. Kanngießer, W. Malzer, A. Fuentes Rodrigues, I. Reiche, Threedimensional micro-XRF investigations of paint layers with a tabletop setup, Spectrochim. Acta Part B 60 (2005) 41-47.

[36] I. Reiche, A. Berger, W. Görner, S. Merchel, M. Radtke, J. Riederer, H. Riesemeier, M. Roth, Following the traces of Albrecht Dürer: analysis of silverpoint drawings by spatially resolved synchrotron-induced X-ray fluorescence analysis, Nucl. Instrum. Methods B 226 (2004) 83-91.

[37] Ž. Šmit, K. Janssens, K. Proost, I. Langus, Confocal $\mu$-XRF depth analysis of paint layers, Nucl. Instrum. Methods B 219-220 (2004) $35-$ 40.

[38] A. Duval, H. Guicharnaud, J.C. Dran, Particle induced X-ray emission: a valuable tool for the analysis of metal point drawings, Nucl. Instrum. Methods B 226 (2004) 60-74.

[39] M. Budnar, J. Simcic, Z. Rupnik, M. Ursic, P. Pelicon, J. Kolar, M. Strlic, In-air PIXE set-up for automatic analysis of historical document inks, Nucl. Instrum. Methods B 219 (2004) 41-47.

[40] A. Zucchiatti, P. Prati, A. Bouquillon, L. Giuntini, M. Massi, A. Miglior, A. Cagnana, S. Roascio, Characterisation of early medieval frescoes by $\mu$-PIXE, SEM and Raman spectroscopy, Nucl. Instrum. Methods B 219 (2004) 20-25.

[41] S. Roascio, A. Zucchiatti, P. Prati, A. Cagnana, Study of the pigments in medieval polychrome architectural elements of 'Veneto-Byzantine' style, J. Cult. Herit. 3 (4) (2002) 289-297.

[42] C. Neelmeijer, M. Mäder, The merits of particle induced X-ray emission in revealing painting techniques, Nucl. Instrum. Methods B 189 (2002) $293-302$.

[43] A. Denker, J. Opitz-Coutureau, Paintings-high-energy protons detect pigments and paint-layers, Nucl. Instrum. Methods B 213 (2004) $677-682$.

[44] A. Denker, O. Hahn, B. Kanngießer, W. Malzer, S. Merchel, M. Radtke, S. Rohrs, Chemistry of arts-non-destructive analysis of artistic and cultural heritage objects, Materialprufung 45 (11-12) (2003) 485-503.

[45] B. Hochleitner, V. Desnica, M. Mantler, M. Schreiner, Historical pigments: a collection analyzed with X-ray diffraction analysis and Xray fluorescence analysis in order to create a database, Spectrochim. Acta Part B 58 (2003) 641-649.

[46] E. Dooryhee, M. Anne, I. Bardies, J.L. Hodeau, P. Martinetto, S. Rondot, J. Salomon, G.B.M. Vaughan, Ph. Walter, Non-destructive synchrotron X-ray diffraction mapping of a Roman painting, Appl. Phys., A 81 (4) (2005) 663-667.

[47] E. Kendix, O.F. Nielsen, M.C. Christensen, The use of micro-Raman spectroscopy in architectural paint analysis, J. Raman Spectrosc. 35 (2004) 796-799. 
[48] A. Brysbaert, P. Vandenabeele, Bronze Age painted plaster in Mycenaean Greece: a pilot study on the testing and application of micro Raman spectroscopy, J. Raman Spectrosc. 35 (2004) 686-693.

[49] R. Mazzeo, P. Baraldi, R. Lujàn, C. Fagnano, Characterization of mural painting pigments from the Thubchen Lakhang temple in Lo Manthang, Nepal, J. Raman Spectrosc. 35 (8/9) (2004) 678-685.

[50] D. Bersani, P.P. Lottici, G. Antonioli, E. Capani, A. Casoli, C. Violante, Pigments and binders in wall paintings of the Santa Mariadella Steccata in Parma (Italy): the ultimate technique of Parmigianino, J. Raman Spectrosc. 35 (8/9) (2004) 694-703.

[51] C. Ricci, I. Borgia, B.G. Brunetti, C. Miliani, A. Sgamelotti, P. Passalacqua, The perugino's palette: integration of an extended in-situ XRF study by Raman spectroscopy, J. Raman Spectrosc. 35 (8/9) (2004) $616-621$

[52] D. Wise, A. Wise, Application of Raman miscrospectroscopy to problems in conservation, authentication and display of fragile works of art on paper, J. Raman Spectrosc. 35 (8/9) (2004) 710-718.

[53] L. Burgio, R.J.H. Clark, K. Theodoraki, Raman microscopy of Greek icons: identification of unusual pigments, Spectrochim. Acta Part A 59 (2003) 2371-2389.

[54] S. Pages-Camagna, A. Duval, H. Guicharnaud, Study of Gustave Moreau's black drawings: identification of the graphic materials by Raman spectroscopy and PIXE, J. Raman Spectrosc. 35 (8/9) (2004) $628-632$

[55] V. Hayez, S. Denoel, Z. Genadry, B. Gilbert, Identification of pigments on a 16th century Persian manuscript by micro-Raman spectroscopy, J. Raman Spectrosc. 35 (8/9) (2004) 781-785.

[56] K. Castro, P. Vandenabeele, M.D. Rodriguez-Laso, L. Moens, J.M Madariaga, Micro-Raman analysis of coloured lithographs, Anal. Bioanal. Chem. 379 (4) (2004) 674-683.

[57] P. Vandenabeele, T.L. Weis, E.R. Grant, L.J. Moens, A new instrument adapted to in situ Raman analysis of objects of art, Anal. Bioanal. Chem. 379 (1) (2004) 137-142.

[58] J.J. Boon, K. Keune, J. van der Weerd, M. Geldof, J.R.J. van Asperen de Boer, Imaging microspectroscopic, secondary ion mass spectrometric and electron microscopic studies on discoloured and partially discoloured smalt in cross-sections of 16th century paintings, Chimia 55 (2001) 952-960.

[59] J. Van der Weerd, J.J. Boon, M. Geldof, R.M.A. Heeren, P. Noble, Chemical changes in old master paintings - dissolution, metal soap formation and remineralisation processes in lead pigmented paint layers of 17 th century paintings, Z. Kunsttechnol. Konservierung 16 (2002) 35 .

[60] K. Keune, J.J. Boon, Imaging secondary ion mass spectrometry of a paint cross section taken from an early Netherlandish painting by Rogier van der Weyden, Anal. Chem. 76 (5) (2004) 1374-1385.

[61] K. Keune, J.J. Boon, Analytical imaging studies clarifying the process of the darkening of vermilion in paintings, Anal. Chem. 77 (15) (2005) $4742-4750$.

[62] Van Loon, K. Keune, J.J. Boon, Improving the surface quality of paint cross-sections for imaging analytical studies with specular reflection FTIR and static SIMS, in: C. Parisi, G. Buzzanca, A. Paradisi (Eds.), Proceedings of the 8th International Conference on "Non-Destructive Investigations and Microanalysis for the Diagnostics and Conservation of the Cultural and Environmental Heritage, Italian Society of Non Destructive Testing Monitoring Diagnostics, Rome, 2005, p. 89.

[63] R. Van Ham, L. Van Vaeck, F. Adams, A. Adriaens, Systematization of mass spectra for the speciation of inorganic salts with static secondary ion mass spectrometry (S-SIMS), Anal. Chem. 76 (9) (2004) 2609-2617.

[64] R. Van Ham, L. Van Vaeck, A. Adriaens, F. Adams, B. Hodges, G. Groenewold, Inorganic speciation in static SIMS: a comparative study between monatomic and polyatomic primary ions, J. Anal. At. Spectrom. 17 (2002) $753-758$.

[65] R. Van Ham, L. Van Vaeck, F. Adams, A. Adriaens, Feasibility of pigment analyses in Medieval paintings and manuscripts with TOFSIMS, Anal. Bioanal. Chem. 383 (2005) 991-997.

[66] J. van der Plicht, K.L. Rasmussen, J. Glastrup, J. Taylor, G. Doudna, Radiocarbon datings of material from the excavation, in: J.B.
Humbert, J. Gunneweg (Eds), Qumran and 'Ain Feshkha II, Academic Press Fribourg, Fribourg, Vandenhoeck and Ruprecht, Goettingen, 2003, p. 193-200.

[67] M. Müller, B. Murphy, M. Burghammer, C. Riekel, M. Roberts, M. Papiz, D. Clarke, J. Gunneweg, E. Pantos, Identification of ancient textile fibres from Khirbet Qumran caves using synchrotron radiation microbeam diffraction, Spectrochim. Acta Part B 59 (2004) $1669-1674$.

[68] A. Adriaens, M. Dowsett, Electron microscopy and its role in cultural heritage studies, in: K. Janssens, R. Van Grieken (Eds.), Non-destructive Microanalysis of Cultural Heritage Materials, Elsevier Science B.V., Amsterdam, 2004, pp. 73-128.

[69] J. Gunneweg, J. Wouters, M. Balla, Qumran and the Dead Sea scrolls: a jigsaw puzzle, in: A. Adriaens, C. Degrigny, J. Cassar (Eds.), Benefits of Non-destructive Analytical Techniques for Conservation, Office for the Official Publications of the European Union, Luxembourg, 2005, pp. 111-122.

[70] J. Gunneweg, M. Balla, Neutron activation analysis: scroll jars and common ware, in: J.-B. Humbert, J. Gunneweg (Eds), Qumran and 'Ain Feshkha, II, Academic Press Fribourg, Fribourg, Vandenhoeck \& Ruprecht, Goettingen, 2003, p. 3-57.

[71] T. Broekmans, A. Adriaens, E. Pantos, Analytical investigations of cooking pottery from Tell Beydar (NE-Syria), Nucl. Instrum. Methods B 226 (2004) 92-97.

[72] T. Broekmans, A. Adriaens, E. Pantos, Insights into North-Mesopotamian 'metallic ware', Archaeometry, in press.

[73] T. Broekmans, A. Adriaens, E. Pantos, Overview of the 3rd millennium BC pottery production technology at Tell Beydar, NESyria, unpublished.

[74] T. Pradell, J. Molera, J. Roque, M. vendrell-Saz, a.D. Smith, E. Pantos, D. Crespo, Ionic-exchange mechanism in the formation of medieval lustre decorations, J. Am. Ceram. Soc. 88 (2005) 1281-1289.

[75] T. Pradell, J. Molera, M. Vendrell, J. Pérez-Arantequi, E. Pantos, M. Roberts, M. Di Michiel, Role of Cinnabar in lustre production, J. am. Ceram. Soc. 87 (6) (2004) 1018-1023.

[76] A. Zucchiatti, A. Bouquillon, G. Lanterna, F. Lucarelli, P.A. Mandò, P. Prati, J. Salomon, M.G. Vaccari, PIXE and $\mu$-PIXE analyzes of glazes from terracotta sculptures of the della Robbia workshop, Nucl. Instrum. Methods B 189 (2002) 358-363.

[77] A. Zucchiatti, A. Bouquillon, J. Castaign, J.R. Gaborit, Elemental analyses of a group of glazed terracotta angels from the Italian Renaissance as a tool for the reconstruction of a complex conservation history, Archaeometry 45 (3) (2003) 391-404.

[78] G. Pappalardo, E. Costa, C. Marchetta, L. Pappalardo, F.R. Romano, A. Zucchiatti, P. Prati, P.A. Mandò, A. Migliori, L. Palombo, M.G. Vaccari, Non-destructive characterization of della Robbia sculptures at the Bargello museum in Florence by the combined use of PIXE and XRF portable systems, J. Cult. Herit. 5 (2004) 183-188.

[79] S. Hreglich, M. Verita, Applications of X-ray-microanalysis to the study and conservation of ancient glasses, Scanning Electron Microsc. Part 2 (1986) 485-490.

[80] Ž. Šmit, K. Janssens, O. Schalm, M. Kos, Spread of façon-de-Venise glassmaking through central and western Europe, Nucl. Instrum. Methods B 213 (2004) 717-722.

[81] Ž. Šmit, P. Pelicon, M. Holc, M. Kos, PIXE/PIGE characterization of medieval glass, Nucl. Instrum. Methods B 189 (2002) 344-349.

[82] D. Jembrih-Simbürger, C. Neelmeijer, M. Mäder, M. Schreiner, X-ray fluorescence and ion beam analysis of iridescent Art Nouveau glassauthenticity and technology, Nucl. Instrum. Methods B 226 (2004) $119-125$.

[83] G. Schultheis, T. Prohaska, G. Stingeder, K. Dietrich, D. JembrihSimburger, M. Schreiner, Characterisation of ancient and art nouveau glass samples by $\mathrm{Pb}$ isotopic analysis using laser ablation coupled to a magnetic sector field inductively coupled plasma mass spectrometer (LA-ICP-SF-MS), J. Anal. At. Spectrom. 19 (7) (2004) 838-843.

[84] C. Neelmeijer, M. Mäder, Reverse painting on glass as seen by the proton beam, Nucl. Instrum. Methods B 226 (2004) 126-135.

[85] R.H. Doremus, Glass Science, Wiley, New York, 1973 
[86] M. Mäder, C. Neelmeijer, Proton beam examination of glass - an analytical contribution for preventive conservation, Nucl. Instrum. Methods B 226 (2004) 110-118.

[87] C. Neelmeijer, M. Mäder, Preventive ion beam inspection of glass treasures, in: A. Adriaens, C. Degrigny, J. Cassar (Eds.), Benefits of Non-destructive Analytical Techniques for Conservation, EUR 21636, Office for Official Publications of the European Communities, 2005, pp. $99-108$.

[88] I. De Ryck, A. Adriaens, E. Pantos, F. Adams, A comparison of microbeam techniques for the analysis of corroded ancient bronze objects, Analyst 128 (2003) 1104-1109.

[89] M.G. Dowsett, A. Adriaens, M. Soares, H. Wouters, V.V.N. Palitsin, R. Gibbons, R.J.H. Morris, The use of ultra-low-energy dynamic SIMS in the study of the tarnishing on silver, Nucl. Instrum. Methods B 239 (2005) 51-64.

[90] D. Scott, Copper and Bronze in Art: Corrosion, Colorants, Conservation, the Getty Conservation Institute, Los Angeles, 2002.

[91] K. Leyssens, A. Adriaens, E. Pantos, C. Degrigny, Study of corrosion potential measurements as a means to monitor the storage and stabilization processes of archaeological copper artefacts, in: J. Ashton, D. Hallam (Eds.), Proceedings of the International Conference on Metals Conservation, National Museum of Australia, Canberra, 2004, pp. $332-343$.

[92] K. Leyssens, A. Adriaens, C. Degrigny, Electrochemical monitoring of the storage or stabilization of archaeological copper based artefacts in sodium sesquicarbonate solutions, Proceedings of the 14th Triennial ICOM-CC Meeting, James and James/Earthscan, London, 2005, pp. 301-309.

[93] A.M. Pollard, R.G. thomas, P.A. Williams, Mineralogical changes arising from the use of aqueous sodium carbonate solutions for the treatment of archaeological copper objects, Stud. Conserv. 35 (1990) 148-152.

[94] C.V. Harie, J.A. Vint, Chalconatronite: a by-product of conservation? Stud. Conserv. 27 (1982) 185-186.

[95] M.G. Dowsett, A. Adriaens, A cell for simultaneous SR-XRD and electrochemical corrosion measurements on cultural heritage metals, Anal. Chem., unpublished.

[96] K. Leyssens, A. Adriaens, M.G. Dowsett, B. Schotte, I. Oloff, E. Pantos, A. Bell, S. Thompson, Simultaneous in-situ time resolved SR-XRD and corrosion potential analyses to monitor the corrosion on copper, Electrochem. Commun. 7 (2005) 1265-1270.

[97] B. Constantinescu, A. Saşianu, R. Bugoi, Adulterations in the first century $\mathrm{BC}$ : the case of Greek silver drachmae analyzed by X-ray methods, Nucl. Instrum. Methods B 58 (2003) 759-765.

[98] R. Linke, M. Schreiner, G. Demortier, The application of photon, electron and proton induced X-ray analysis for the identification and characterization of Medieval coins, Nucl. Instrum. Methods B 226 (2004) $172-178$.
[99] A. Denker, J. Opitz-Coutureau, M. Griesser, R. Denk, H. Winter, Nondestructive analysis of coins using high-energy PIXE, Nucl. Instrum. Methods B 226 (1-2) (2004) 163-171.

[100] S. Santra, D. Mitra, M. Sarkar, D. Bhattacharya, A. Denker, J. OpitzCoutureau, J. Rauschenberg, Analysis of some coins by energy dispersive X-ray fluorescence (EDXRF) and high energy particle induced X-ray emission (PIXE) techniques, Nucl. Instrum. Methods B 229 (3-4) (2005) 465-470.

[101] M.F. Guerra, T. Calligaro, Gold cultural heritage objects: a review of studies of provenance and manufacturing technologies, Meas. Sci. Technol. 14 (2003) 1527-1537.

[102] A. Perea (Ed.), El tesoro Visigodo de Guarrazar, CSIC, Ministerio de Educación, Cultura y Deporte, Universidad de Castilla-La Mancha, Diputación Provincial de Toledo, 2001 (in Spanish).

[103] A. Perea, I. Montero, G. Demortier, A. Climent-Font, Analysis of the Guerrazar treasure by PIXE, in: G. Demortier, A. Adriaens (Eds.), Ion Beam Study of Art and Archaeological Objects, Office for the Official Publications of the European Union, Luxembourg, 2000, pp. 99-101.

[104] M.Á. Ontalba Salamanca, B. Gómez Tubío, M.L. de la Bandera, M.Á. Respaldiza, PIXE-PIGE analysis of a visigothic gold cross, Nucl. Instrum. Methods B 226 (2004) 199-207.

[105] O. Enguita, A. Climent-Font, G. Garcia, I. Montero, M.E. Fedi, M. Chiari, F. Lucarelli, Characterization of metal threads using differential PIXE analysis, Nucl. Instrum. Methods B 189 (2002) 328-333.

[106] D. Vella, C. Degrigny, M. Grech, A. Williams, Metallurgy of armour exhibited at the Palace Armoury Valletta, Malta, in: J. Ashton, D. Hallam (Eds.), Metal 04 Proceedings of the International Conference on Metals Conservation, National Museum of Australia, Canberra, 2004, pp. 215-233.

[107] E.H. Lehmann, P. Vontobel, E. Deschler-Erb, M. Soares, Non-invasive studies of objects from cultural heritage, Nucl. Instrum. Methods A 542 (2005) 68-75.

[108] M.F. Guerra, Fingerprinting ancient gold with proton beam of different energies, Nucl. Instrum. Methods B 226 (2004) 185-198.

[109] A.G. Karydas, D. Kotzamani, R. Bernard, J.N. Barrandon, Ch. Zarkadas, A compositional study of a museum jewellery museum collection (7th1st BC) by means of a portable XRF spectrometer, Nucl. Instrum. Methods B 226 (2004) 15-28.

[110] B. Constantinescu, R. Bugoi, V. Cojocaru, D. Voiculescu, D. Grambole, F. Herrmann, D. Ceccato, Romanian ancient gold objects provenance studies using micro-beam methods: the case of "Pietroasa" hoard, Nucl. Instrum. Methods B 231 (2005) 541-545.

[111] R. Bugoi, V. Cojocaru, B. Constantinescu, F. Constantinescu, D. Grambole, F. Herrmann, Micro-PIXE study of gold archaeological objects, J. Radioanal. Nucl. Chem. 257 (2) (2003) 375-383. 